\title{
Innovation, Entrepreneurship and Education Management Based on Science and Technology Innovation
}

\author{
Shanshan sun \\ Jilin Institute of Chemical Technology, No.45, Chengde Street, Longtan District, Jilin City, Jilin \\ Province, China \\ sunshanshan_jlict@163.com
}

\section{Keywords: Technology innovation; Entrepreneurship; Entrepreneurship Education}

\begin{abstract}
In the era of knowledge economy, socio-economic development urgently needs science and technology entrepreneurial talents, relying on scientific and technological innovation advantages, and establishing close relationships with socio-economic development in terms of scientific and technological personnel innovation, innovation, technology transfer and industrialization of scientific and technological achievements. In this context, entrepreneurship education will be based on scientific and technological innovation and will form its own characteristics. Giving full play to the positive role of entrepreneurship education in talent cultivation requires a dialectical view of the relationship between education, science and technology, and economics. In order to adapt to the needs of socio-economic development and rely on scientific and technological innovation, it is necessary to find a suitable path for the development of entrepreneurship education.
\end{abstract}

\section{Entrepreneurship Education and Related Concepts}

Innovation and Technological Innovation. In the book "Nanshi • Houhui Story • Volume one • Song Shizu Yin Shuyi" is the first book to involve "innovation", innovation is to create or create something new. The definition of innovation in China's "Ci Hai" is: "Create new innovations." In 1912, the American economist Joseph Alois Schumpeter pointed out in his "Introduction to Economic Development": "Innovation is the introduction of a new combination of production factors and production conditions into a production relationship." An innovative theory includes the following five situations: "One is the development of new products; the second is the use of new production methods; the third is the discovery of new markets; the fourth is the discovery of new sources of supply and access to new raw materials or semi-finished products; five are the creation of new The industrial and industrial organizations in Sichuan have introduced the concept of "innovation" in China's science and technology and other related fields, and in the 1990's, they were presented in terms of "knowledge, culture, scientific and technological innovation" and "independent innovation". It is ubiquitous and quickly integrated into different areas of people's economy and society. Some scholars interpret "innovation" from the connotation of ordinary life and from the perspective of economics. In simple terms, innovation is "creating and discovering new things."

Innovation can be explained in terms of both broad and narrow innovations. The broad sense of innovation can be either a concept or a new "thing" appearing in action, or it can be regrouped by relying on technology or education. In the narrow sense of innovation, the key to any exploration, creation, correction, or re-aggregation in terms of theory, measures, or skills is to stop at the intersection of economic development and technological capabilities. Relatively speaking, the broad sense of innovation is more of a creation at the thinking level, innovative, aggressive, courageous, and courageous to open up and transform the spirit and attitude. It also includes innovations with extremely low technological content or zero technology. Social innovation, management innovation, institutional innovation, etc. will not only have more innovative opportunities and opportunities, but will also generate huge benefits or gains from them." It can thus be seen that when we say that innovation is the essence and soul of entrepreneurship, it is by no means understood and grasped from the perspective of inventions and innovations and technological innovations, but from 
"entrepreneurship motives" and "creative entrepreneurs' cognition of innovation". Analysis of the "market acceptance of innovation" perspective. It has a unique inspection perspective and profound implication, and has certain scientific and rational nature. Peter Drucker, a master of management, used the example of "payment in installments" and believed that "innovation does not necessarily have to be related to technology, and sometimes it does not need to be specific".

Entrepreneurship and technology ventures. The interpretation of entrepreneurship in the "Modern Chinese Dictionary" is the founding of a business. It includes the words "creation" and "industry." "Innovation" is the creation and creation, and "industry" is the meaning of business and business. "Overall, it can be divided into broad sense and narrow sense. Broadly speaking, narrowly defined entrepreneurship refers specifically to the establishment of a business enterprise, and broadly defined entrepreneurial business just refers to the creation of a business or the inclusion of innovative behavior. The broad sense of entrepreneurship is almost everything, including small production lines. One specific improvement on the implementation of the aerospace plan is that the narrow sense of entrepreneurship can be based on innovation, or it can be based on imitation.In entrepreneurial practice, imitating entrepreneurship is far more than innovation and entrepreneurship, because any competition in the market is in the minority. Under the mobilizer's model, a large number of followers imitate the formation of joins."

Entrepreneurial connotation is richer, and its extension is also broader. For the time being, entrepreneurial entrepreneurship is defined as "referring to entrepreneurs who take risks and creatively integrating existing resources in the socio-economic, cultural, and political realms by finding and grasping entrepreneurial opportunities or opportunities. Create new organizations, new businesses, new businesses, new jobs, and start new businesses, so that opportunities for the realization of new goods or new services are identified and created, creating a whole process of new value for everyone and society." It can be seen that entrepreneurship places more emphasis on the creation of actions. Entrepreneurship refers to all activities that have pioneering and innovative features that can enhance economic value or social value. Entrepreneurship can not only increase employment opportunities, but also enable a successful career. Student entrepreneurship plays an important role in China's economic and social development. It not only becomes the source of education system reform and the development of new and high technology, but also the source of prosperity for the socialist market economy and accelerating the economic development of our country. Undergraduate entrepreneurship can not only alleviate employment problems. , but also for more people to increase employment opportunities, but also the implementation of the needs of building an innovative national strategy.

\section{The current status of entrepreneurship education in China's technology colleges}

From the historical data of college entrepreneurship education in China, the entrepreneurship education at the polytechnic colleges has not formed an independent field since the beginning. In recent years, it has mainly been influenced by the requirements of socio-economic development. Entrepreneurship education in polytechnic colleges has only begun to emerge. Gradually formed a more independent area. Divided by time and development trend, the development process of China's polytechnic colleges generally includes three stages.

Early stage of entrepreneurship education. "In November 1989, UNESCO organized an international conference for education in the 21 st century in Beijing. The conference discussed the educational philosophy of the 21 st century, including 9 issues, of which the 7 th question is about learning. The issue of three passes, namely, dedication and the development of skills passes." Requirement to increase dedication and pioneering skills to the same level as academic and vocational education passes.

"In the second half of 1990, as a joint education innovation project country to improve young people's entrepreneurial abilities, the Ministry of Basic Education of the former State Education Commission took the lead and set up a project national coordination group to carry out entrepreneurship education research. The relevant research was also listed as the State Education Commission. Eighty-five educational science planning projects and entrepreneurship education 
were conducted in 20 counties, townships, and more than 30 schools in 6 provinces and cities." After two phases of research, some suggestions on entrepreneurship education were obtained, and entrepreneurship education series of books were published. A number of research achievements have conducted a preliminary understanding of entrepreneurship education goals, courses, and continuing education in the areas of entrepreneurship education, entrepreneurship education, quality education, and entrepreneurship education.

Participation of polytechnic colleges in piloting pioneering education. "In 2002, the Ministry of Education chose Renmin University of China, Tsinghua University, Nanjing University of Finance and Economics, Xi'an Jiaotong University, Wuhan University, Northwestern Polytechnical University, Beijing University of Aeronautics and Astronautics, Shanghai Jiaotong University, and Heilongjiang University as pilot universities for entrepreneurial education to conduct entrepreneurship education. Practical exploration." Among them, the performances of Tsinghua University, Beijing University of Aeronautics and Astronautics, and Shanghai Jiaotong University are quite typical. Here is a brief introduction of the experimental conditions of entrepreneurship education in these three institutions. The forms of entrepreneurship education at Tsinghua University include entrepreneurship enlightenment, entrepreneurship courses, entrepreneurial competitions, and entrepreneurship practices. "The 'Tsinghua-Berkeley Global Technology Venture Project' is a featured course at Tsinghua University and is taught by Chinese and foreign professors in bilingual language." Marking Tsinghua University as a pilot institution, it began to actively radiate and export entrepreneurial education outside the school.

Beijing University of Aeronautics and Astronautics established the Entrepreneurship Management Training Institute in early 2002, and formed a system with the technology incubator and science park to form a training platform for entrepreneurship. As of 2011, the institute has successfully held the first trainer training course for the KAB Entrepreneurship Education (China) Project, the KAB Entrepreneurship Education Project Teacher Training Course, and the KAB Entrepreneurship Education (China) Project for the third lecturer training class.

Shanghai Jiao Tong University was established in 2002 and 2009 by the Ministry of Education and Shanghai Municipality as pilot universities for entrepreneurship education. In June 2010, the Institute of Entrepreneurship was established to explore the "one body, two wings," entrepreneurial education model for research universities.

Accelerating the Development of Entrepreneurship Education in Technological Colleges. After the first 10 years of development in the 21st century, entrepreneurship education has achieved certain results and it has entered a period of accelerated development. In 2009, the Ministry of Education established the Steering Committee for Entrepreneurship Education in Colleges and Universities and on May 4th issued the Opinions on Promoting Innovative and Entrepreneurial Education in Higher Education Institutions and Self-employment for College Students, and urged all localities to vigorously promote innovation and entrepreneurship education and achieve breakthroughs.

The following brief introduction to the basic practices of entrepreneurship education in these institutions: The entrepreneurship education of Dalian University of Technology began after innovation education and developed together with it. The integration of innovation education and entrepreneurship education is a distinctive feature of entrepreneurship education in Dalian University of Technology, or can be said to be the direction of entrepreneurship education in the university. However, this integration is still in the exploratory stage of Dalian University of Technology, as opposed to its innovative education. Its entrepreneurial education has not yet reached the effect that should be achieved after perfect integration of innovation education and entrepreneurship education.

Tongji University takes entrepreneurship education as a new talent training model and incorporates it into its entire university education system. "In September 2006, Tongji University established the Shanghai University Student Science and Technology Foundation for the Promotion of Technology Entrepreneurship at Tongji University. In November 2007, the Tongji University College of Business Development was established. Unlike many colleges and universities, the 
Science and Technology Pioneering Park is different. The Pioneering Park has highlighted the support for the teachers and students in their scientific and technological entrepreneurship."

\section{The development of entrepreneurship education in China's technology colleges}

Entrepreneurship education in technology colleges is constantly evolving. Under the ever-increasing trend of the knowledge economy, based on the close relationship between the polytechnics and socio-economic development, and on the role of entrepreneurship education in the cultivation of talents in polytechnic colleges and their own development, it is possible to foresee entrepreneurship in polytechnic colleges. Some prospects for educational development.

The degree of intrusion into social and economic development will be further improved. There is a close relationship between science and technology universities and science and technology-related talents, achievements, and enterprises. It plays a role by providing support for scientific and technological personnel and achievements in social and economic development. The development of social economy is promoted through the establishment of a technology-based enterprise or participation in the establishment and management of technology-based enterprises. At the same time, through these activities, the development of the colleges and universities of science and technology can also make considerable progress. The entrepreneurial education based on scientific and technological innovations implemented by the colleges and universities will also be more deeply penetrated into the development of the social economy.

Pay more attention to entrepreneurship education based on scientific and technological innovation. In reality, educational activities that have played a positive and relatively direct impetus to the development of social economy have received extensive attention. For entrepreneurship education, entrepreneurial education based on scientific and technological innovation, which provides a large number of scientific and technological talents and technological innovations for social and economic development, is attracting more attention. Therefore, the degree of concern of science and technology entrepreneurship education in China's polytechnic colleges will be further deepened in the future.

Pay more attention to cross-school and cross-professional cooperation in entrepreneurship education. Since the purpose of entrepreneurship education in polytechnic colleges is to promote students' all-round development, it is not just a matter of emphasizing what science and engineering education can do. Therefore, it is necessary to further strengthen the cooperation between polytechnic colleges and internal specialties in science and engineering, economics, management, or business studies. If these polytechnics lack such specialties, they must select appropriate institutions to carry out relevant cooperation, that is, cross-school cooperation. It can be foreseen that in the process of advancing science and technology entrepreneurship education, China's polytechnic colleges will not strengthen their "professionalism" in their professional fields, but will also be more active in strengthening internal guidance and outreach to achieve complementary professional and off-campus disciplines in schools.

Further influence the orientation of talent training objectives in polytechnic colleges. Judging from the reality and anticipation of social and economic development, graduates of science and engineering who are narrow in technology and do not understand operations and management will find it difficult to meet the higher requirements of social and economic development, and foster social capabilities, innovation, leadership and comprehensive capabilities. Is very important. Based on this appeal of the socio-economic development to the cultivation of talents in polytechnic colleges, entrepreneurial education based on scientific and technological innovation will have an impact on the orientation of talent training goals in some polytechnic colleges. The implementation of entrepreneurship education will have an impact on the knowledge structure of students in universities and colleges of science and technology, and advance their direction towards the development of compound talents. This will create the possibility for polytechnic colleges to cultivate compound talents; at the same time, compound talents cultivated through entrepreneurship education will be more to meet the actual needs of social and economic development, this will, to a certain extent, in turn promote the adjustment of science and technology colleges and universities to 
adjust their talent training goals.

Deep intervention in cooperation between production, teaching and research. Technological colleges have established close links with socio-economic development in terms of personnel training for scientific and technological innovation, scientific and technological innovation, and provision of patented products, transformation of scientific and technological achievements, and so on, making polytechnic colleges active in the cooperation of "production, study and research", and their implementation. Entrepreneurship education also draws on the cooperation platform of "production, study and research" to acquire resources and expand the space for practice. From the current point of view, the cooperation of "producing, researching, and researching" has created superior conditions for entrepreneurship education in colleges and universities. With the development of innovative entrepreneurial talents for the technological colleges and universities and social and economic development, the importance of supporting policies for entrepreneurship has been continuously innovated. With the continuous deepening of the education system reform, the entrepreneurship education activities at the polytechnic colleges will establish a closer and more direct relationship with industry, universities and research institutes, and promote mutual development through interaction.

\section{References}

[1] R. Liu: "Exploration of Innovation and Entrepreneurial Education Model in Contemporary Chinese Art Colleges", Xi' an Academy of Fine Arts, 2017-03-01.

[2] W.B. Yang: "Study on the Mode and Operational Mechanism of Entrepreneurial Education in Colleges and Universities", Southeast University, 2016-06-13.

[3] J. Chen: "Research on the Construction of University-led Entrepreneurial Education Ecological System", Northeast Normal University, 2017-05-01.

[4] H.Shang: "Research on Innovation and Entrepreneurial Education Model in Colleges and Universities", Nanjing University of Science and Technology, 2017-03-01.

[5] C.G. Han: "Research on the Evaluation of Entrepreneurial Ability of Science and Engineering Students", Beijing University of Science and Technology, 2015-03-19.

[6] L. Cao: "Research on Undergraduates' Innovation and Entrepreneurship Education under the New Normal", Jinzhou Medical University, 2017-05-01.

[7] H. Lu: "Empirical Study on Government Responsibility in Innovation and Entrepreneurial Education in Universities", Nanjing Normal University, 2017-04-18.

[8] G. Liu: "Study on the evaluation of college students' entrepreneurial policy effectiveness", Tianjin University, 2016-05-01.

[9] X. Chen: "A Practical Research on the Entrepreneurship Education in Chinese Universities", Jiangxi University of Finance and Economics, 2017-06-01.

[10] Y.L. Wang: "Study on the Underpinning Environment of China's University Students' Science and Technology Entrepreneurship", Northeastern University, 2014-06-01.

[11] X.L. Zhao: "Study on Innovation and Entrepreneurial Education of Chinese Undergraduates in the Times of Public Creation", Jinan University, 2017-05-25.

[12]X. Zhang: Research on Entrepreneurship Education in Agricultural Universities, Nanjing Agricultural University, 2014-06-01.

[13] S. Lin: "The Construction Path and Practice of the "Four in One" Entrepreneurial Education System", Fuzhou University, 2014-03-01.

[14] D.Z. Nan: "Study on Innovation Ability Cultivation of College Students of Science and Engineering", Shandong University, 2017-10-09.

[15] W.T. Xu: "Study on Quality Guarantee Mechanism of Entrepreneurship Education in Universities", Southwest University, 2016-04-10.

[16] G.R. Zhang: "Study on Collaborative Mechanism for the Cultivation of Innovative Talents in Colleges and Universities", Shanxi University, 2017-06-01. 